\begin{tabular}{|c|c|c|}
\hline & $\begin{array}{c}\text { Bioeduca: Journal of Biology Education } \\
\text { http://journal.walisongo.ac.id/index.php/bioeduca } \\
\text { ISSN 2086-9324 (print) }\end{array}$ & BBOEDUECA \\
\hline WALISONGO & $\begin{array}{c}\text { Volume 1, Nomor 1, Tahun } 2019 \\
\text { Hal. } 12-17\end{array}$ & \\
\hline
\end{tabular}

\title{
Pengetahuan Mahasiswa Institut Agama Islam Negeri Kerinci Tentang Teori Asal Usul Manusia
}

\author{
Dharma Ferry ${ }^{1 *}$, Tomi Apra Santosa ${ }^{2}$, Dairabi Kamil ${ }^{3}$ \\ 1,2,3Tadris Biologi, Institut Agama Islam Negeri Kerinci \\ *Email: dharmaferry@iainkerinci.ac.id
}

\begin{tabular}{|c|c|}
\hline Informasi Artikel & ABSTRAK \\
\hline $\begin{array}{l}\text { Submit: } 10-08-2019 \\
\text { Diterima: } 12-08-2019 \\
\text { Dipublikasikan: } 31-09-2019\end{array}$ & $\begin{array}{l}\text { Evolusi adalah salah satu cabang ilmu biologi yang masih } \\
\text { menjadi kontroversi. Penelitian ini bertujuan untuk mengetahui } \\
\text { pengetahuan mahasiswa jurusan Biologi tentang asal usul } \\
\text { manusia. Jenis penelitian merupakan penelitian kualitatif dengan } \\
\text { pendekatan fenomena. Partisipan adalah mahasiswa Biologi dan } \\
\text { mahasiswa Pendidikan Agama Islam dari Institut Agama Islam } \\
\text { Negeri Kerinci. Teknik pengumpulan berupa wawancara dan } \\
\text { dokumentasi. Hasil penelitian ini menunjukkan bahwa } \\
\text { pengetahuan mahasiswa Biologi dari segi sains menyatakan } \\
\text { bahwa (1) manusia berasal dari nenek moyang yang sama } \\
\text { dengan kera, (2) manusia berasal dari makhluk hidup } \\
\text { sebelumnya, selanjutnya dari segi agama, menyatakan bahwa } \\
\text { manusia berasal dari tanah. Pengetahuan mahasiswa } \\
\text { Pendidikan Agama Islam dari segi sains menyatakan bahwa (1) } \\
\text { manusia berasal dari nenek moyang yang sama dengan kera, (2) } \\
\text { manusia berasal makhluk hidup sebelumnya, selanjutnya dari } \\
\text { segi agama menyatakan bahwa (1) manusia berasal dari tanah, } \\
\text { (2) manusia berasal dari Nabi Adam dan Hawa. } \\
\text { Kata kunci: asal-usul manusia; evolusi; sains dan agama. }\end{array}$ \\
\hline Penerbit & ABSTRACT \\
\hline $\begin{array}{l}\text { Program Studi Pendidikan } \\
\text { Biologi, Fakultas Sains dan } \\
\text { Teknologi, UIN Walisongo } \\
\text { Semarang }\end{array}$ & $\begin{array}{l}\text { Evolution is a branch of biology that is still controversial. This } \\
\text { study aims to determine the knowledge of students majoring in } \\
\text { human origins. This type of research is qualitative research with } \\
\text { a phenomenon approach. Participants were Biology students and } \\
\text { Islamic Education students from Institut Agama Islam Negeri } \\
\text { Kerinci. Interview and documentation techniques. This study } \\
\text { indicates that biology students' knowledge in terms of science } \\
\text { states that (1) humans come from the same ancestor as apes, (2) } \\
\text { humans come from previous living creatures, then from a } \\
\text { religious perspective, they state that humans come from the land. } \\
\text { The knowledge of Islamic Education students in terms of science } \\
\text { states that (1) humans come from the same ancestor as apes, (2) } \\
\text { humans come from previous living creatures, then from a } \\
\text { religious perspective which states that (1) humans come from the } \\
\text { ground, (2) humans come from the ground, (2) humans come } \\
\text { from the Prophet Adam and Eve. } \\
\text { Keywords: evolution; human origins; science and religion. }\end{array}$ \\
\hline
\end{tabular}

Copyright $\odot 2019$, Bioeduca: Journal of Biology Education 


\section{PENDAHULUAN}

Evolusi biologi adalah perubahan dari waktu ke waktu pada satu atau lebih sifat terwariskan yang dijumpai pada populasi organisme (Hassan et al., 2014). Evolusi hanya bisa terjadi bila ada variasi sifat yang diwariskan dalam populasi. Sumber utama variasi adalah mutasi, rekombinasi genetik, dan aliran gen (gene flow). Evolusi telah membentuk keanekaragaman makhluk hidup dari nenek moyang yang sama (Hassan et al., 2014). Kita dapat mendefinisikan evolusi sebagai keturunan dengan modifikasi, istilah yang digunakan Darwin dalam menjelaskan bahwa dari kejadian yang terjadi dibumi ini, banyak spesies keturunan dari spesies leluhur yang dulu berbeda dari spesies masa kini. Evolusi juga bisa didefinisikan sebagai perubahan komposisi genetik suatu populasi turun-temurun (Campbell et al., 2017). Pikiran tentang evolusi sudah ada ratusan tahun sebelum masehi yang muncul dari pemikiran ahli-ahli filsafat Yunani kuno dan belum didasarkan pada fakta yang akurat serta belum dikaitkan dengan lingkungannya. Pemikiran tentang evolusi kembali berkembang melalui tokoh evolusi organik zaman Renaisans pada abad 17 yang lebih banyak mendasari teori Darwin.

Teori evolusi yang dicetus oleh Darwin menibulkan kegemaran yang luar biasa di dunia Barat seabad yang lalu karena teori tersebut bertentangan sama sekali dengan kisah penciptaan manusia dan alam semesta yang dianut oleh masyarakat pada saat itu. Teori evolusi Kontroversial itu diuraikan oleh Darwin dalam On the Origin of Spesies by Means of Natural Selection pada tahun 1859, disusul kemudian dengan The Descent of Man and Selection in Relation Sex yang terdiri dari dua jilid pada tahun 1871. Jangka waktu dua belas tahun sejak terbitnya The Origin of Spesies, para ilmuwan hampir semua telah sepakat mendukung teori evolusi, sedangkan para agamawan dengan keras tetap menentangnya (Junaidi, 2017). Darwin berpendapat bahwa manusia berasal dari makhluk-makhluk yang lebih rendah derajatnya manusia, lalu berevolusi sampai bentuknya seperti sekarang, sedang para agamawan berkeyakinan bahwa Nabi Adam adalah manusia pertama yang langsung dicipta Tuhan dalam bentuk seperti sekarang tanpa melalui evolusi (Junaidi, 2017).

Hubungan antara sains dan agama semakin menunjukkan pertentangan. Sains berasal dari kata Science, Scienta, Scine, Scienta, Scine yang artinya mengetahui. Kata lain sains adalah logos, sendi dan ilmu. Sains dapat diartikan ilmu pengetahuan yang mempunyai tujuan sebagai mencari kebenaran dengan berdasarkan kepada fakta atau fenomena alam. Agama merupakan segenap kepercayaan (kepada Tuhan, Dewa) dan kebaktian serta kewajiban-kewajiban yang bertalian dengan kepercayaan itu (Sodikin, 2003). Teori Darwin pada zaman modern ini masih diperdebatkan di kalangan akademisi di perguruan tinggi, termasuk di Institut Agama Islam Negeri Kerinci. Institut Agama Islam Negeri Kerinci memiliki salah satu jurusan yang di identik dengan sains yakni jurusan tadris biologi. Jurusan Tadris biologi merupakan jurusan yang telah berdiri sejak 2006. Mahasiswa tadris biologi khsususnya yang berada di semester 6 terdapat mata kuliah tentang evolusi. Materi asal usul manusia pada matakuliah evolusi merupakan salah satu materi yang membangkitkan kontroversi 
sains dan agama di kalangan mahasiswa. Cara untuk melihat kontroversi yang terjadi di jurusan biologi tentang asal usul manusia yaitu melalui pengatahuan dan persepsi.

Pengetahuan adalah segala sesuatu yang telah diketahui. Cara untuk mengetahui sesuatu dapat dilakukan dengan cara mendengar, melihat, merasa oleh mahasisa biologi dan mahasiswa Pendidikan Agama Islam. Persepsi ialah proses penilaian seseorang terhadap suatu objek. Dalam hal ini, sudut pandang mahasiswa biologi (sains) dan Mahasiswa Pendidikan Agama Islam (agama) tentan asal usul manusia. Berdasarkan latar belakang diatas peneliti ingin mendeskripsikan pengetahuan mahasiswa jurusan biologi dan Pendidikan Agama Islam. Penelitian ini bertujuan untuk mengetahui pengatahuan mahasiswa jurusan biologi dan Pedidikan Agama Islam tentang asal usul manusia: Studi komparatif antara mahasiswa jurusan biologi dan Pendidikan Agama Islam.

\section{METODE PENELITIAN}

Penelitian ini merupakan penelitian kualitatif. Penelitian kualitatif merupakan metode-metode untuk mengekplorasi dan memahami makna yang oleh sejumlah individu atau sekolompok orang yang dianggap berasal dari masalah sosial atau kemanusian (Creswell, 2010). Informan penelitian ini adalah mahasiswa biologi yang telah mempelajari mata kuliah evolusi dan mahasiswa Pendidikan Agama Islam yang mempelajari mata kuliah IImu Alamiah Dasar (IAD). Teknik pengumpulan data berupa wawancara dan dokumentasi. Wawancara adalah pertemuan dua orang untuk bertukar informasi dan ide melalui tanya jawab, sehingga dapat dikontruksikan makna dalam suatu data tertentu (Saebani, 2008). Wawancara yang digunakan ialah wawancara semiterstruktur. Dokumentasi yaitu mengumpulkan bahan tertulis seperti berita di media, notulen-notulen rapat, surat menyurat dan laporan-laporan untuk mencari informasi yang diperlukan (Afrizal, 2017) Teknis analisis data digunakan anaisis data Miles and Huberman yang meliputi Reduction, Dislay dan Verification.

\section{HASIL PENELITIAN DAN PEMBAHASAN}

\section{Pengatahuan Mahasiswa Biologi tentang Asal Usul Manusia}

Pengetahuan mahasiswa biologi dari segi sains menyatakan bahwa asal usul manusia itu berasal dari nenek moyang yang sama dengan kera yang mengalami evolusi. Mahasiswa biologi mengetahui asal usul tersebut berdasarkan ditemukannya fosil manusia. Fosil merupakan sisa - sisa makhluk hidup yang telah membatu dalam kurun jutaan tahun yang lalu. Selain itu juga ditemukannya spesies- spesies kera yang berevolusi menjadi manusia zaman dahulu seperti Pithecantropus erectus, manusia kera berdiri tegak yang fosilnya berumur sekitar 400 ribu tahun, Homo neanderthelensis, manusia Neanderthal yang fosilnya berumur kira-kira 100 ribu tahun (Kuniawati et al., 2018)

Evolusi adalah perubahan ciri-ciri populasi yang berlangsung seiring waktu (Mayr, 2010). Penemuan fosil merupakan salah satu sumber yang dijadikan bukti-bukti evolusi. Penemuan fosil ditemukan di beberapa tempat di berbagai negara. Manusia pertama kali berevolusi di Afrika timur sekitar 2,5 juta tahun yang lalu dari satu genus 
kera yang lebih awal yang dinamakan Autralopithecus yang berarti kera selatan (Harari, 2017). Penemuan bukti fosil juga ditemukan di Indonesia, tepat di pulau Jawa ditemukan bukti fosil Homo Soloensis atau manusia dari lembah Solo. Penemuan juga terjadi di Flores, yakni ditemukan spesies manusia yang bernama Homo florensis yang mempunyai tinggi 1 meter dan mempunyai berat kurang lebih 25 kilogram. Homo florensis ini sudah mampu menghasilkan peralatan dari batu dan bahkan kadangkadang mereka berhasil berburu gajah-gajah di pulau tersebut.

Pengetahuan mahasiswa biologi dari segi agama menyatakan bahwa asal usul manusia itu dari saripati tanah. Tanah itu mengandung unsur organik dan anorganik yang dibutuh oleh manusia untuk berkembagbiak. Bahan - bahan itu seperti protein, karbohidrat, mineral, dan vitamin semua itu berasal dan hidup dari tanah. Di dalam AlQur an Allah sudah menjelaskan hal tersebut sebagaimana firman Allah dalam surat Al-Mu'minun ayat 12-14 yang artinya:

"Dan sesungguhnya Kami telah menciptakan manusia dari suatu saripati (berasal) dari tanah, Kemudian Kami jadikan saripati itu air mani (yang disimpan) dalam tempat yang kokoh (rahim), Kemudian air mani itu Kami jadikan segumpal darah, lalu segumpal darah itu Kami jadikan segumpal daging, dan segumpal daging itu Kami jadikan tulang belulang, lalu tulang belulang itu Kami bungkus dengan daging. Kemudian Kami jadikan dia makhluk yang (berbentuk) lain. Maka Maha sucilah Allah, Pencipta Yang Paling Baik".

\section{Pengetahuan Mahasiswa Pendidikan Agama Islam tentang Asal usul Manusia}

Mahasiswa Pendidikan Agama Islam menyatakan pengetahuan tentang asal usul manusia dari sains dan agama. Pengetahun dari segi agama mahasiswa Pendidikan Agama Islam menyatakan bahwa: (1) asal usul manusia itu dari Tanah, (2) asal usul manusia itu dari Adam dan Siti Hawa. Adanya Perbedaan ini terjadi karena berbeda dalam memahami kontekstual dari Al-Qur'an. Mahasiswa Pendidikan Agama Islam yang mengatakan asal usul manusia dari tanah. Tanah adalah tempat tumbuh dan berkembangnya manusia, dan dari unsur bumi pula Allah menciptakan manusia, di bumi manusia hidup dan dari pula manusia di bangkitkan untuk mempertanggungjawabkan semua apa yang telah mereka lakukan selama hidup di dunia (Ikhwani, 2014). Mengenai asal manusia itu dari tanah Allah SWT berfirman dalam Q.S. Al-Shad ayat 71 yang artinya:

"Ingatlah, ketika Tuhanmu berfirman kepada malaikat: sesungguhnya Aku akan menciptkan manusia dari Tanah".

Pendapat mahasiswa Pendidikan Agama Islam menyatakan asal usul manusia itu dari Nabi Adam karena mereka memahami firman Allah dalam Q.S. Al-Hijr ayat 26 artinya:

"Dan sesungguhnya Kami telah menciptakan manusia (Adam) dari tanah liat kering (yang berasal) dari lumpur yang diberi bentuk".

Ayat menjelaskan bahwa Allah menciptakan secara langsung manusia yakni Adam sebagai manusia pertama di bumi. 
Pengetahuan mahasiswa Pendidikan Agama Islam tentang asal usul manusia dari segi sains (teori evolusi) menyatakan bahwa asal usul manusia itu dari nenek moyang kera dan juga berasal dari makhluk hidup yang sebelumnya. Pengetahuan mahasiswa Pendidikan Agama Islam mengatakan bahwa secara sains (teori evolusi) manusia berasal dari nenek moyang kera dan makhluk hidup sebelumnya disebabkan pengalaman mereka waktu belajar biologi di bangku Sekolah Menengah Atas (SMA). Pengetahuan atau pengalaman manusia dapat didapat dari hubungan manusia dengan lingkungan melalui alat Indra, bukan melalui pikiran (Sugiyono dan Tamzil, 2013).

\section{SIMPULAN DAN SARAN}

Mahasiswa biologi dan mahasiswa Pendidikan Agama Islam memiliki pengetahuan yang hampir sama mengenai asal usul manusia dari segi sains dan agama. Pengetahuan mahasiswa biologi dari segi sains menyatakan bahwa (1) asal usul manusia berasal dari nenek moyang yang sama dengan kera, (2) asal usul manusia dari makhluk hidup sebelumnya, sedangkan dari segi agama menyatakan bahwa asal usul manusia dari tanah. Pengetahuan mahasiswa Pendidikan Agama dari segi sains menyatakan bahwa (1) Asal usul menusia itu berasal dari nenek moyang yang sama dengan kera, (2) asal usul manusia itu berasal makhluk hidup sebelumnya, (3) Asal usul manusia berasal dari manusia sebelumnya, sedangkan dari segi agama menyatakan bahwa (1) Asal usul manusia itu berasal dari tanah, (2) Asal usul manusia itu berasal dari Nabi Adam dan Hawa. Adanya persamaan pengetahuan antara mahasiswa biologi dan mahasiswa pendidikan agama islma dikarenakan mahasiswa pendidikan agama islam memiliki pengalaman belajar biologi pada saat belajar di Sekolah Menengah Atas (SMA).

\section{UCAPAN TERIMA KASIH}

Terima kasih kepada Ketua Jurusan Tadris Biologi IAIN Kerinci beserta segenap mahasiswa. Terima kasih juga kepada segenap pimpinan di Fakultas Tarbiyah dan IImu Keguruan IAIN Kerinci. Kepada semua pihak yang telah banyak membantu dan memberi dukungan pada penelitian ini, penulis juga mengucapkan banyak terima kasih. Semoga penelitian ini dapat menjadi acuan untuk penelitian selanjutnya.

\section{RUJUKAN}

Afrizal. (2017). Metode Penelitian Kualitatif. Depok: Rajawali Pers.

Campbell, N.A., Reece, J. B., Urry, L.A. (2017). Biology (Eleventh Edition). New York: Pearson.

Creswell, John W. (2009). Reseach Design :Pendekatan Kualitatif, Kuantitatif, dan Mixed. Yogyakarta: Pustaka Pelajar.

Hassan, Munif Said. (2014). Pengantar Biologi Evolusi. Jakarta: Erlangga.

Harari, Yuval Noah. (2017). Sapiens: Riwayat Singkat Umat Manusia. Jakarta: Kepustakaan Populer Gramedia.

Junaidi, Helmi. (2010). Adam dan Hawa Bukan Manusia Pertama: Teori Evolusi dan Asal Usul Manusia di Dalam Al-Qur'an. Yogyakarta.

Kurniawati, Eka \& Nurhasanah Bakhtiar. (2018). Manusia Menurut Konsep Al-Qur'an 
Vol. 1, No. 1 (2019), Hal. $12-17$

dan Sains. Jurnal Of Natural Science and Integration, 1(1), http://dx.doi.org/10.24014/jnsi.v1i1.5198

Mayr, Ernest. (2010). Evolusi: Dari Teori ke Fakta. Jakarata: Kepustakaan Populer Gramedia

Saebani, Beni Ahmad. (2008). Metode Penelitian. Bandung: Pustaka Setia.

Sodikin, R. (2003). Konsep Agama dan Islam. Al Qalam, 20(97):1-20, DOI: http://dx.doi.org/10.32678/alqalam.v20i97.643.

Sugiono \& Tamzil. (2012). Filsafat Pendidikan. Bandung: PT. Remaja Rosdakarya. 